\title{
TO THE PROBLEM OF THE RECONSTRUCTION OF THE EARLY STAGES OF THE HISTORY OF THE CHURCH SLAVONIC TRANSLATION OF THE AKATHISTOS HYMN
}

The Akathistos Hymnos - one of the greatest masterpieces of Byzantine hymnography - from the earliest times managed to pass the borders of the culture, where it had originated. Among the cultures, which were influenced to the greatest extent by this hymn the Slavonic culture should probably be mentioned first, due to the great popularity of the text among Slavs through all the history of the Slavonic Orthodoxy from the $10^{\text {th }}$ century until nowadays, as well as due to the specific tradition of original Slavonic hymns - "akathist" - composed by the model of the hymn.

Being the part of the Orthodox Church year service (it is the only kondak which is still read completely in church), the text of the Akathistos should be involved into the set of books necessary for the performance of the liturgical service. These books had to be translated in the first years of Christianization of Slavs. Though no Slavonic manuscript containing the text of the hymn has reached us to prove this suggestion, most of the researchers ${ }^{1}$ tend to believe that the translation of the Akathistos happened in the $9^{\text {th }}$ century, and the translation was made by the adapts of Kurillos and Methodios. However, it should be mentioned, that it remains unknown in the content of which liturgical book the Akathistos was originally translated. The researches who

(1) See, for example, С. Ю. ТЕмчин, Этапы становления славянской гимнографии (863 - около 1097 г.). Часть первая, Славяноведение 2 (2004) 18-55, esp. 42.; А. А. Турилов, Акафист Богородице. Источники, in: Православная энизиклопедия, т. 1 (Москва, 2000) 372; Б. Н. Флоря, А. А. Турилов, С. А. Иванов, Судьбы Кирилло-Мефодиевской традицุии после Кирилла и Мефодия (Санкт-Петербург: Алетейя, 2000) 10-14. 
claim that the hymn was translated inside the Triodium ${ }^{2}$ seem not to take into account the fact, that Akathistos had changed its liturgical place in the services of the Greek Orthodox Church - as one can easily see from the Greek manuscripts, up to the $10^{\text {th }}$ century it had been generally read on the fest of Annunciation ( $25^{\text {th }}$ of March), and only later it was moved to its present place - the Saturday of the $5^{\text {th }}$ week of the Great Lent. ${ }^{3}$ So up to the $10^{\text {th }}$ century the hymn had been the part of the other liturgical book - the Minaia, and it seems logical to suppose that the first acquaintance of Slavs with the Akathistos happened in the content of this book, and only lately $\left(10^{\text {th }}-12^{\text {th }}\right.$ century) the Slavonic text of the hymn was transferred to the Triodium, following the example of the new type of corresponding Greek liturgical books. However though the earliest manuscripts of Minaia of March dates back to the $13^{\text {th }}$ century, the only manuscripts that contain the hymn up to the $14^{\text {th }}$ century, are Triodia as well as a few West Slavonic Kondakaria, from which only one, namely the oldest one named Typografsky, presents the full text of the Akathistos.

It has been noticed in literature ${ }^{4}$ that two South Slavonic Triodium: the Bulgarian one named Shafarikovskaia (F. n. I. 74 from the National Public Library of Saint-Petersburg) and the Serbian one (F. n. I. 68 from the National Public Library of Saint-Petersburg) contain the other version of the hymn, which will be called below version $A$, quite different from the one of the other South Slavonic and East Slavonic manuscripts. The main peculiarity of the version A appears to be the attempt of the translator to organize the Slavonic text in such a way as to hold in the translation the acrostic principle of the original, which happened to result in the significant changes both in the content and in the form of the hymn. Besides in this Slavonic text one can see a plenty of mistakes, inaccurate translations, as well as phrases which sound ambiguous or even mean-

(2) М. А. МоминА, Греческие разночтения в славянских гимнографических текстах, ВВ 44 (1983) 127; Турилов, Акафист..., 372.

(3) E. Wellesz, The Akathistos Hymn, in: Monymenta Musicae Byzantinae. Transcripta, vol. 9 (Copenhagen, 1957) 14; C. A. Trypanis, Fourteen Early Byzan-

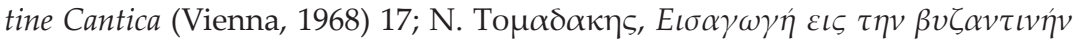

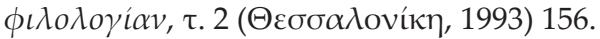

(4) В. Мошин, Кирилски рукописи Югославенске Академие (Загреб, 1955) 212-213; М. А. МоминА, Постная и Цветная Триоди. Содержание Триоди (состав служб), in: Методические рекомендации по описанию славяно-русских рукописей для Сводного каталога рукописей, хранящихся в СССР, vol. 2 (Москва, 1976) 389-418, esp. 417. 
ingless. Naturally, the number of such mistakes has been increasing after each re-writing of the text, so that in the manuscripts of $13^{\text {th }}-14^{\text {th }}$ century one can hardly recognize in the jumbled separate incomprehensible Slavonic strophes their harmonic Greek original. However there do exist both paleographic and linguistic evidences that make us, as well as the other researchers ${ }^{5}$ to believe that this was the first Slavonic translation of the hymn and to attribute it to one of the adapts of Kurillos and Methodius, namely to Konstantin Preslavsky or to Kliment Okhridsky. It is worth mentioning, that the very principle of acrostic can be considered as an indication on these persons as the possible translators, since in their original hymns both Konstantin Preslavski and Kliment Okhridski generally use the acrostics, both alphabetical and thematic.

This Slavonic text being so imperfect, that in fact it could not function as a liturgical unit, it seems no wonder that sooner or later the attempts would happen to replace it by a better one. In such way one can explain the appearance of the other version of the translation, the one on which all the later versions of the Slavonic text up to the modern one are based (below version $B$ ). Let us stress that the new version appeared to be not a revision of the first translation, but another translation performed from another Greek manuscript. One can see from the comparison of one arbitrary chosen strophe - oikos (oikos 8) of two versions that the differences between them, which are underlined, exceed $50 \%$.

\begin{tabular}{|c|c|c|}
\hline Greek text & $\begin{array}{l}\text { Version A - } \\
\text { Triodium } \\
\text { Shafarikovskaja }\end{array}$ & $\begin{array}{l}\text { Version B - } \\
\text { Kontakario } \\
\text { Typografsky }\end{array}$ \\
\hline 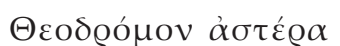 & мыскъно Бжї̈ Пхть & БОГОТЕЧЬHОУЮ ЗВЕЗАУ \\
\hline$\theta \varepsilon \omega \varrho \eta ́ \sigma \alpha \nu \tau \varepsilon \varsigma \mu \alpha ́ \gamma \overline{\mathrm{O}}$ & внАЬВШЕ вАЪХВИ & вНАЬВЪШЕ ВЪАСви \\
\hline 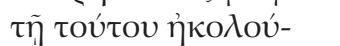 & 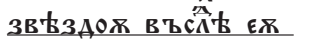 & по ТОН въса中доваша \\
\hline$\theta \eta \sigma \alpha v \alpha{ }^{\prime \prime} \gamma \lambda \eta$ & ПОСАЬАОВАВЬШЕ & зарн н гако \\
\hline 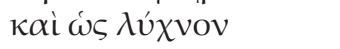 & гако св ТТниннка & св'ТТнАьннка Аьржаще \\
\hline 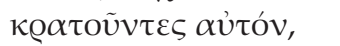 & ЗрАШЕ Н ЗанЪ & ю тою пытаху \\
\hline$\delta \iota^{\prime} \alpha u ̛ \tau o \tilde{v} \eta \dot{\varrho} \varrho \dot{v} \omega \omega$ & въпрашах & крtпъкаго цесара \\
\hline$\kappa \varrho \alpha \tau \alpha$ เòv $\alpha \ddot{v} \alpha \kappa \tau \alpha$. & АрьжАџаго & И ПОстИГЪШЕ \\
\hline$\kappa \alpha i ̀ ~ \phi \theta \alpha ́ \alpha \alpha \nu \tau \varepsilon \varsigma$ & вьсьчъскал & неПОстнЖнМаГО \\
\hline 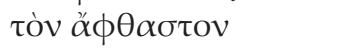 & И ПОСТИГШЕ & радовашаса еMУ \\
\hline 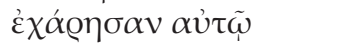 & неПОстНЗаЕМаГО & ВЪПнющЕ \\
\hline $\begin{array}{l}\beta 0-\tilde{\omega} \nu \tau \varepsilon \varsigma^{\circ} \\
\dot{\alpha} \lambda \lambda \eta \lambda \text { oúi } \alpha .\end{array}$ & 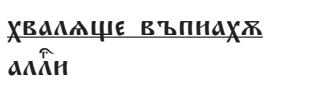 & anîyra \\
\hline
\end{tabular}

(5) See, for example, М. А. Момина, Типы славянской Триоди, in: Язык и письменность среднеболгарского периода (Москва, 1982) 102-122, еsp. 114. 
One can also notice from the comparison that while the text of the version A is in fact a very "free" translation of the original, the version $B$ presents a really true translation, which follows the Greek text with word after word preciseness and, though it does not manage to represent some poetical figures of the original, including the acrostic, and has a number of "clumsy" Slavonic words and phrases, as well as several mistakes, results in a satisfactory equivalent of the Greek hymn.

The problem of the determination of the time and the place of composition of this version still remains open. Let us mention, that the determination of the origin of the text by the analyses of the language of manuscripts is proved to be a wrong way, ${ }^{6}$ though, as it has been shown in recent studies, the local graphical, phonetic, morphological and lexical variants could have been brought into the text later by the scribes who didn't hesitate to alter the text in order to adapt it to one of the regional variants - the so-called izvod of Church Slavonic. The only valid judgment about the translation's origin should be based on a critical analysis of the complete codicological and textological tradition.

In modern slavistics, in particular among representatives of Russian school, the answer is usually believed to be provided by the speculations of M. Momina ${ }^{7}$ about the so-called "general revision" of all the books used in the liturgical practice which happened, according to the scholar, in the $11^{\text {th }}$ century Kiev Rus'. The opinion of M. Momina is based on the impressing fact, that the East Slavonic tradition of liturgical books up to the $14^{\text {th }}$ century is quite different from the South Slavonic one. First, in the Kiev Rus' existed several types of books, namely the Kontakaria and the Hyrmologia that have never been found in the oldest South Slavonic tradition. Second, the other liturgical books of the East Slavonic origin provide the revised version of the South Slavonic ones, the significant differences between the versions showing the systematic editor's work over the text. Thus, for Triodium - the liturgical book of a particular interest for our research - the separate

(6) Г. Г. ДАнт, Еще раз о мнимых переводах в Древней Руси, ТОДРД 51 (1999) 435-441; Fr. J. Thomson, "Made in Russia": A Survey of the Translations Allegedly Made in Kievan Russia, in: Millenium Russiae Christianae. Tausend Jahre Christliches Russland 988-1988: Vorträge des Symposiums anlasslich der Tausendjahrfeier der Christianisierung Russlands (Köln, 1993) 295-354, esp. 298-302.

(7) М. А. МоминА, Проблема правки славянских богослужебных гимнографических книг на Руси в 11 в., ТОДРЛ 45 (1992) 200-219. 
type Gimovsky is distinguished for the East Slavonic region. The scholar claims, that this type stayed unknown in the South Slavonic tradition, which used the other types Shaforikovsky and Orbelsky, according to her own classification. ${ }^{8}$ These facts were interpreted as evidence of the systematic revision of South Slavonic liturgical books in the Kiev Rus', which was performed due to translation and adoption of the other type of the Typicon (namely the Typicon of Alexej Studit) directly from the Byzantium without the Bulgarian mediation. It is worth mentioning, that since the performance of such a large volume of translators' and editors' work should necessary involve the efforts of a group of qualified scholars with excellent knowledge of both Greek and Slavonic language, the speculations of M. Momina could be considered in the context of the long-term discussion of the so-called Kiev Rus' translation school. ${ }^{9}$

According to the opinion of M. Momina ${ }^{10}$ the second version of the Slavonic text of the Akathistos was composed in the process of this revision, i. e. in the Kiev Rus' in the end of the $11^{\text {th }}$ century. Let us stress that this fact if proved with sufficient data from the manuscripts has to play the critical role in the argumentation in support of the whole speculation. In fact, besides of the Triodium of the East Slavonic version, the full text of the Akathistos is included in the oldest Slavonic Kontakario Tipografsky (the end of the $11^{\text {th }}$ - the beginning of the $12^{\text {th }}$ century), which written together with the oldest copy of the Slavonic translation of the new Typicon, is believed to be the most authentic text resulted from the hypothetic revision. Thus, if the revision described by M. Momina really took place, it should certainly include the revision of the Akathistos. On the contrary, if it turns out, that the composition of the second version of Akathistos has nothing to do with the Kiev Rus' of the $11^{\text {th }}$ century, it would be a serious argument against the whole speculation.

The greatest difficulty of the study is the absence of any manuscript representing the South Slavonic tradition of the Akathistos up to the very end of the $12^{\text {th }}$ century. Thus we can only suppose what happened

(8) М. А. МоминА, Вопросы классификации славянской Триоди, ТОДРИ 37 (1983) 25-37, esp. 31.

(9) See, for example, А. И. Соболевский, Особенности русских переводов домонгодьского периода, Сборник отделения русского языка и словесности 88 (1910) 162-177; А. А. АлЕксевв, К истории русской переводческой школы 12 в., ТОДРЯ 41 (1988) 154-196.

(10) МоминА, Проблема правки..., 218. 
with the text in the whole period of $9^{\text {th }}-12^{\text {th }}$ centuries in this region. The number of Bulgarian, Macedonian and Serbian manuscripts that reached us from the period of the $13^{\text {th }}$ - beginning of the $14^{\text {th }}$ century is also very small and has such a great variety of versions of the text, that it seems really very difficult to reconstruct the relations between them, as well the initial text's versions. Besides the acrostic translation, there exists the version of translation with the same order of oikoi as in the Greek text, which significantly differs however from the East Slavonic version B - the version contained, for example, in the Serbian Triodium Kopitarova, ${ }^{11}$ which we will call later version $C$. These two South Slavonic traditions (versions $\mathrm{A}$ and $\mathrm{C}$ ) were mixed in the number of ways, making almost every manuscript unique. On the contrary, the East Slavonic tradition of the $11^{\text {th }}-14^{\text {th }}$ century is represented by the relatively large number of manuscripts with a similarity among the texts, that definitely proves that they all descend from one source..$^{12}$ All the differences between the East Slavonic manuscripts could be explained as mistakes of the scribes, and up the $15^{\text {th }}$ century no conscious change had been made in the text. The fact that the full text of this type hasn't been found in the South Slavonic manuscripts seems at the first glance to support the opinion of the East Slavonic origin of the version B.

However the more careful revision of the South Slavonic versions of the Akathistos has to be based on the more detailed analyses of the whole text of the hymn in order to examine the possible mutual influences of different versions. And this analysis reveals some interesting facts.

The first interesting remark appears after the detailed comparison of the text of the version B with the text of the manuscripts F. n. I. 68 and F. n. I. 74 containing the acrostic version A. As it was stated above, generally the differences between the versions exceed $50 \%$ of the whole text. However in the certain fragments of the text, namely in the koukoulion and in the oikoi 1, 2 and 3 the differences between the versions are less than $5 \%$, and all of them do not involve the systematic editor's work over the text, but rather seem to have originated from the mistakes of the scribes, as one can easily see comparing the texts of koukoulion in two manuscripts:

(11) A. Filonov-Gove, The Slavic Akathistos Hymn. Poetic Elements of the Byzantine Text and its Old Church Slavonic Translation (Munchen, 1988) 223-275; Т. С. БорисовА, К истории ранних редакций церковнославянского пере-

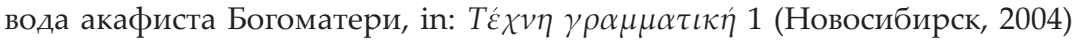
40-57, esp. 44- 46.

(12) БорисовА, К истории..., 55-56. 
F. n. I. 68

ВЪЗБранномУ воєводТ ПОБВаБнаА

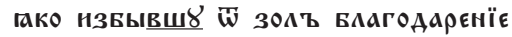
вЪСПнСАЕТЬ ТН ГРААЪ ТВОН БЦЕ но гако нм४џн АрьжавУ

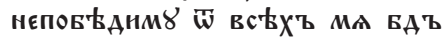
СВОБОАН Аа 30 В ТИ рӓнсА невЊсто вєзневЊстнаА
Kondakarion Typografsky

ВъзБраньномУ воєводЬ пов'АьнаА ГаКО НЗБЫВЪ W ЗЪАЪ БААГОААРЕННА вЪСПнСАЕТЬ ТИ ГРААЪ ТВОН БЦЕ нъ гако нм४щїн АьржавУ НєПОББАНМУ СВОБОАН АА ЗОВУ ТН

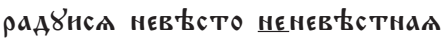

Such similarity could not be a coincidence. It seems quite clear that these fragments, in the opposition to the rest of the text, have the same origin. In fact two explanations of this phenomenon could be offered. First, a translator of the version B could use the certain fragment of the version A instead of making his own translation. Second, these fragments in their present form are not the ones which the version A originally contained. In this case we have to admit that for some reasons the certain parts of the initial text were substituted lately by the corresponding ones from the version $B$.

The analysis of the texts provides us with the facts which tend us to believe in the second explanation. Let us stress that due to the changed order of oikoi in version $\mathrm{A}$, caused by the need to form acrostic, the certain oikos as well as the koukoulion are in the different parts of the hymn and do not form one fragment as it happens in version $B$. Thus if we assume that the translator of the version $B$ used this fragments of the version $\mathrm{A}$, then he would have to refer to the whole text, and the fact that he used only these parts and neglected the others finds no logical explanation. On the contrary, the certain strophes form the very beginning of the hymn in the version B and so could be easily separated from the rest of the text and for some reasons unknown to us used in the revision of the version A. Moreover, the very style of these strophes with the word for word translation, exactness and relatively small amount of mistakes and inadequate translations is similar to the one of the version $B$ and indicates their common origin.

The further reason to believe that the certain strophes are not the ones which the version A originally contained, but appeared in the text later under the influence of the version B is provided by the analyses of another South Slavonic manuscript - the so called Zagreb Macedonian Triodium of the beginning of the $14^{\text {th }}$ century (Zagreb Macedonian Archive, IV d 107, below ZMT). ${ }^{13}$ Though the manuscript was

(13) I would like to thank Prof. Horace G. Lunt for the copy of the manuscript. 
written one century later than the Triodium Shafarikovskaja, it is commonly believed to reflect the earliest stages of the history of the Slavonic Triodium. In fact, some researchers tend to consider it the earliest version of the Triodium that reached us. ${ }^{14}$

A mere glance on the text of Akathistos of ZMT reveals that it doesn't belong to any of the versions mentioned above, neither to the other South Slavonic versions of the Akathistos. In fact, the very order of oikoi of the Akathistos in this particular manuscript is unique. This fact made M. Momina to believe that the text presents the separate version of Akathistos, which had appeared as initial text revision according to the Greek origin..$^{15}$ This speculation however doesn't explain the strange structure of the hymn, which has nothing to do either with the following of the structure of the Greek text, nor with an attempt of its conscious change for poetical purpose, as it had happened in version A. On the contrary, at the first glance it seems to lack any system at all (see Picture 1).

\section{Picture 1. Comparison of the Structure of The Zagreb Macedonian Triodium with the Structures of Versions A and B}

\begin{tabular}{|c|c|c|c|}
\hline B & 123 & 456 & 7891011121314151617181920212 \\
\hline ZMT & 161 & 1252 & $1013 \quad 141516171819202122$ \\
\hline 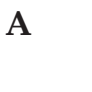 & $\begin{array}{l}1611 \\
\text { part I }\end{array}$ & $\begin{array}{l}274 \\
\text { part II }\end{array}$ & $\begin{array}{c}1320322514198910232415181716212 \\
\text { part III }\end{array}$ \\
\hline
\end{tabular}

In order to understand this structure we should examine it from another aspect. Basing on the order of oikoi the whole text could be easily divided into three parts. The very beginning of the text excluding the koukoulion follows the same order of oikoi as in the version A, in other words the first three oikoi are oikoi 1, 6 and 11 according to their order in the Greek text. The second part doesn't seem to follow the order of oikoi either of the version A, nor of the version B. This part contains oikoi 12, 5 and 2, i. e. the oikoi, which form pairs with the oikoi of the first part of the text. It is obvious that the text's composer added this part in order to complete the pairs of oikoi of the first part and thus in some way to unite the sources he used. In the third part the order of oikoi follows the one of the Greek origin (and the version B as well), omitting naturally the oikoi which were used in the first two parts. This unique order of oikoi has the only one logical

(14) Л. СлАвевА, Структурната еволуција на јужнословенските триоди, in: Т. Стаматоски (eds.), Климент Охридски: Студии (Скопје, 1986) 87-88.

(15) Момина, Греческие разночтения..., 127. 
explanation - this text is a compilation composed from two Slavonic versions of text of different origin. The first source of this compilation seems to represent the version A with its acrostic structure, while the second has the same order of oikoi as in the Greek Akathistos.

Let us mention that phenomena of such kind are quite a common event in Slavonic manuscript tradition. ${ }^{16}$ Compilation of various sources or various versions of the same text was not considered as forbidden or negative in the cultural sense practice. On the contrary, the choice between different sources and their combination in the new more or less original structure was the only way in which the scribes could express their own cultural preferences and act as co-creators of the text. The compilator's work doesn't require the knowledge of Greek language, which not many even educated Slavs possessed that time, nor the philological abilities, necessary for performing translations of revisions. In fact the only thing necessary for compilation is the co-existence of at least two different versions of the same text. It is no wonder that wherever the different versions of the Akathistos co-existed in the same time and place, they were united in the compilations of different kind.

It should be stressed that compilation as a literature phenomenon has been almost neglected in the philological studies. As far as the full description of this type of Old Slavonic texts has not been made, compilations are often confused with the new systematic text's revisions ${ }^{17}$. However, the compilations provide the most valuable material for the researcher, including the information on the versions of the text which co-existed in the certain territory over the certain period of time. It is quite a common event, that versions, which have not saved "in full" could be found in the content of compilation. Moreover, the researchers that analyze the text basing on the manuscripts which were written several centuries later after the text's translation or composition - a situation quite common in the Old Slavonic studies - are to keep in mind that in reality they have to do not with the separate versions of the text, but with their later composed compilations.

The compilation we have to do with in the Akathistos of ZMT is a rather mechanical one. The compilator started his text copying one of the versions of the Slavonic Akathistos - namely the one with the

(16) Т. С. БорисовА, К определению понятия текстологической компиляции (на материале рукописной истории церковнославянского пе-

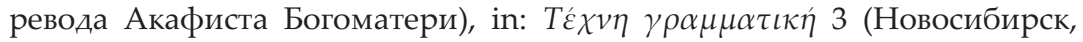
2008) 80-99.

(17) See, for example, Момина, Греческие разночтения..., 127. 
acrostic, and finished it following another source - the version without the acrostic. The second part seems to be a rather clumsy attempt to harmonize these mutually incompatible parts and to give some image of system to this by all means chaotic structure.

Since the source of the first part of the compilation appears to be the acrostic version of the Akathistos, it seems logical to expect the text of this part to coincide with the beginning of the text of the version A. Indeed, in oikoi 6 and 11 the texts are almost the same; the minimal differences are likely to originate from the scribes' mistakes. In the text of oikos 1, however, the differences are so significant that they reveal another version, or even translation of this fragment. Let us stress that the version of oikos 1 of ZMT has not been found in any other manuscript, nor could it be explained by the influence of any other Slavonic or Greek source. Comparing the texts of oikos 1 of ZMT with the one of F. n. I. 74, one can easily see that the style of the former text is similar to the style of the version A in general, in other words it has a number of mistakes, inadequate translations and incomprehensible Slavonic phrases (see Table 1), while the second text, as we stated above, seems to show greater similarity with the version $B$.

Table 1. Two versions of Slavonic translations of oikos 1 of the Akathistos (from the manuscripts F. n. I. 74 (Triodium Shafarikovskaja) and IV d 107 (Zagreb Macedonian Triodium) the differences between the versions are underlined.

\begin{tabular}{|c|c|c|c|}
\hline Line & Greek text & F. n. I. 74 . & $\begin{array}{c}\text { Zagreb Macedonian } \\
\text { Triodium }\end{array}$ \\
\hline 1 & 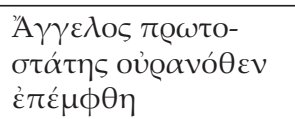 & 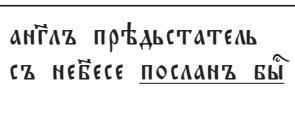 & 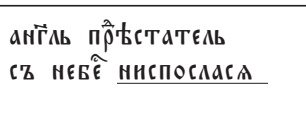 \\
\hline 2 & 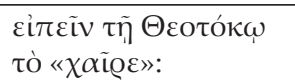 & рєчн Бц̆и ра̂̀нсА & рєчи вцेн ра̄षсА \\
\hline 3 & 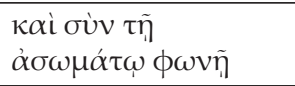 & $\begin{array}{l}\text { НСС БеСПАZТZНЫМЬ } \\
\text { ГААМЬ }\end{array}$ & 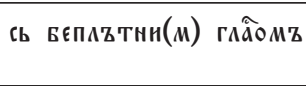 \\
\hline 4 & 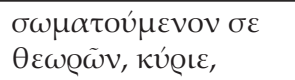 & $\frac{\text { ВZПАZчьшасА }}{\text { ТЕ ГНЖ }}$ & $\begin{array}{l}\text { ВZПАZЩЕна ТА ВНжАА } \\
\text { Г̈Н }\end{array}$ \\
\hline 5 & 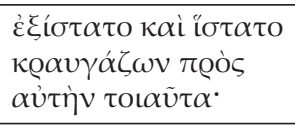 & $\begin{array}{l}\text { АНВААШЕСА И СТОГАШЕ } \\
\text { ВZПНА КZ НЕН } \\
\text { ТАКОБАГ } \\
\end{array}$ & $\begin{array}{l}\text { АНБНжесА И СТоРАШЕ } \\
\text { ВZПНА К НЕН СНЦЕ }\end{array}$ \\
\hline 6 & $\begin{array}{l}\chi \alpha \tilde{\mathrm{i}} \varepsilon, \delta \iota^{\prime} \tilde{\eta} \varsigma \dot{\eta} \chi \alpha \varrho \dot{\alpha} \\
\dot{\varepsilon} \kappa \lambda \alpha \dot{\alpha} \mu \psi \varepsilon \iota^{\circ}\end{array}$ & $\begin{array}{l}\text { ра̂̆нсA єю жє вZсїА } \\
\text { радость }\end{array}$ & 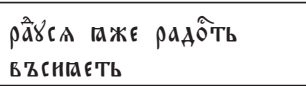 \\
\hline 7 & $\begin{array}{l}\chi \alpha \tilde{i} \varrho \varepsilon, \delta \iota^{\prime} \tilde{\eta} \varsigma \dot{\eta} \dot{\alpha} \varrho \dot{\alpha} \\
\dot{\varepsilon} \kappa \lambda \varepsilon \varepsilon \dot{\psi} \psi \varepsilon \iota^{\circ}\end{array}$ & 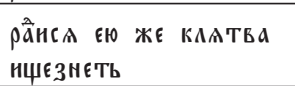 & 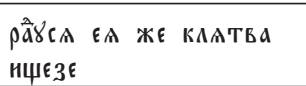 \\
\hline
\end{tabular}




\begin{tabular}{|c|c|c|c|}
\hline Line & Greek text & F. n. I. 74. & $\begin{array}{c}\text { Zagreb Macedonian } \\
\text { Triodium } \\
\end{array}$ \\
\hline 8 & 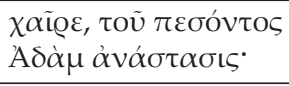 & $\begin{array}{l}\text { pầnсA падьшаго } \\
\text { адама вZстанїє } \\
\end{array}$ & $\begin{array}{l}\text { păbca падьшаго ада(M) } \\
\text { вZскрБшєнїє }\end{array}$ \\
\hline 9 & 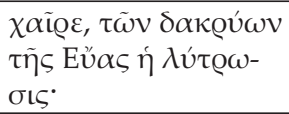 & $\begin{array}{l}\text { ра̂̀нсА сАь弓Z євжннZ } \\
\text { НЗБАВАєнїє }\end{array}$ & 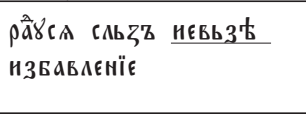 \\
\hline 10 & 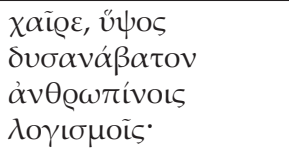 & 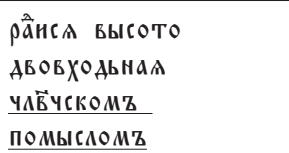 & $\begin{array}{l}\text { рӓвса высото } \\
\text { АБовьходнаА ЧйкомZ } \\
\text { МнсавнаА }\end{array}$ \\
\hline 11 & 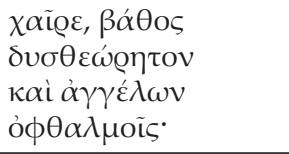 & 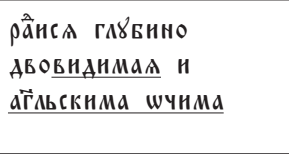 & 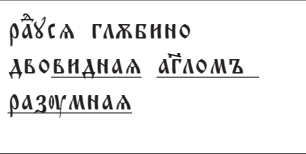 \\
\hline 12 & 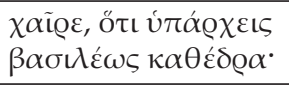 & 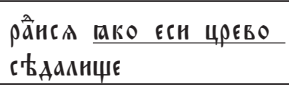 & 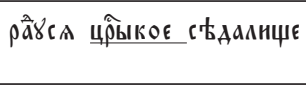 \\
\hline 13 & 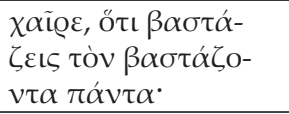 & 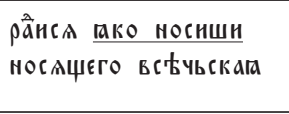 & 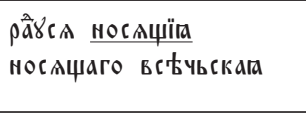 \\
\hline 14 & 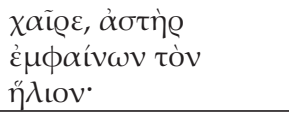 & 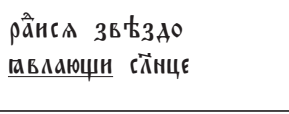 & 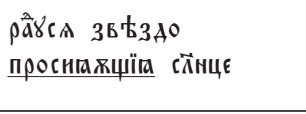 \\
\hline 15 & 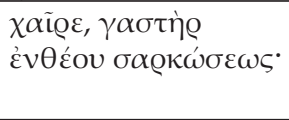 & 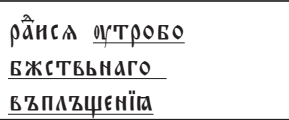 & 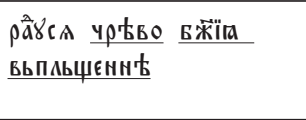 \\
\hline 16 & 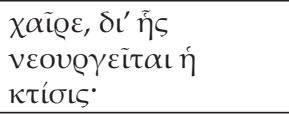 & 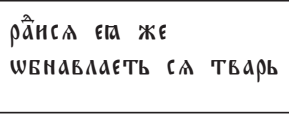 & 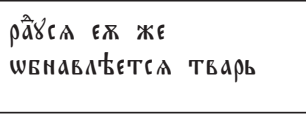 \\
\hline 17 & 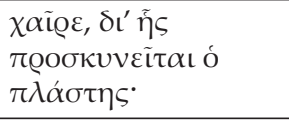 & 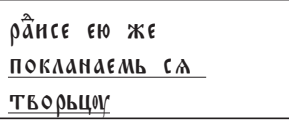 & $\begin{array}{l}\text { рӓвса прБкланћниемь } \\
\text { Твонмz }\end{array}$ \\
\hline 18 & $\begin{array}{l}\chi \alpha \tilde{i} \varrho \varepsilon, v u ́ \mu \phi \eta \\
\dot{\alpha} v \tilde{\mu} \mu \varepsilon v \tau \varepsilon .\end{array}$ & 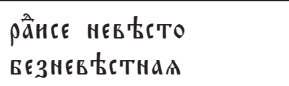 & 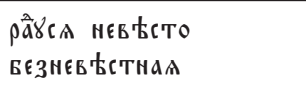 \\
\hline
\end{tabular}

All these facts put together make us to believe that the compilation of ZMT saves the initial variant of the first oikos of version A, which in the other manuscripts had been changed under the influence of another source. Unfortunately, oikoi 2 and 3 are in the other parts of the compilation of ZMT, and so they were probably of another origin. That's why we couldn't reconstruct their initial form in the acrostic version. However in these strophes we do have several variants, which could have originated from the initial acrostic version. They are:

oikos 2, line 2 - the Greek $\theta \alpha \varrho \sigma \alpha \lambda \varepsilon ́ \omega \varsigma$ is translated св дрьзновєнїємz, while the other versions have крьпц', 


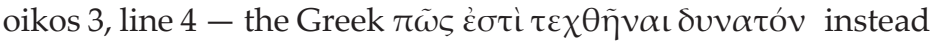
of како єсть родити іิџно of the other versions is translated како възМожно есть РОдити,

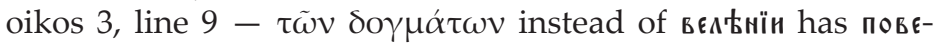
А'ьнїємь,

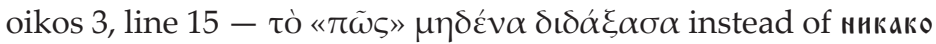
же ннедннаго навчьши is translated гако никакоже никогоже повчниа ECH,

and finally

oikos 3, line 17 - ф@évas instead of смыслz presents the variant разоумни мискь.

These facts give us another strong argument in support of our speculation about the version B origin of oikoi 1, 2 and 3 of the manuscripts F. n. I. 74 and F. n. I . 68, which for some reasons unknown to us have been put into place of the initial ones which saved only in part in the compilation of ZMT. Let us stress, that in this case the manuscripts F. n. I. 68 and F. n. I. 74 don't present the authentic type of the acrostic version, but its compilation with the version $\mathrm{B}$.

Let us return to the analyses of the Akathistos of $\mathrm{ZMT}$, which will reveal the other interesting facts concerning the version $\mathrm{B}$. As we stated above, one of the sources of this compilation was the acrostic version of the Akathistos. In order to determine the other source, let us examine more closely the third part of the hymn, which according to our speculations was taken from it. The analysis of the structure of the text has revealed that in this version the order of oikoi of the hymn was the same as in the Greek origin. Thus we have to search the origin of the third part among the versions without acrostic. Our investigations on the topic have shown, that up to the 14th century there existed only two such versions. The first one was the version B described above. Let us remember, that this version is found "in full" only in the East Slavonic manuscripts. The second version (version C) is the one found only in the South Slavonic manuscripts, either "in full" (the version of Triodium Kopitarova), either in compilation with the acrostic version A (Triodium Orbelskaja). ${ }^{18}$ Since the compilation of ZMT was definitely composed in the South Slavonic territory, it would seem logical to expect it to use the South Slavonic version as its source. However, the comparison of the most significant differences between the versions $B$ and $C$ with the variants of ZMT shows definitely, that the compilation used the version B.

(18) БорисовА, К истории..., 53-54. 


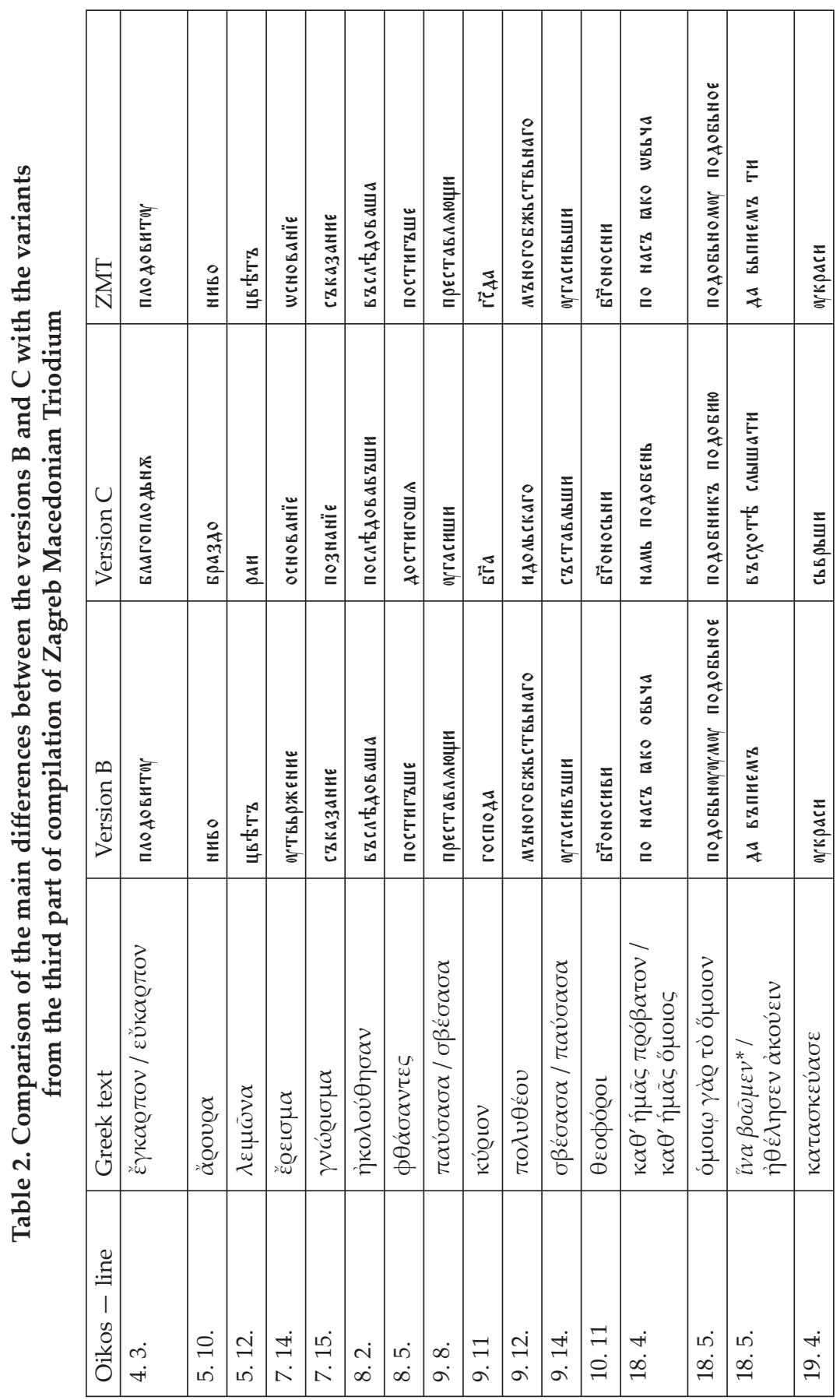




\begin{tabular}{|c|c|c|c|c|c|c|c|c|c|c|c|c|c|c|c|}
\hline$\sum_{N}$ & $\begin{array}{l}\frac{5}{5} \\
\frac{5}{5} \\
\frac{5}{5}\end{array}$ & 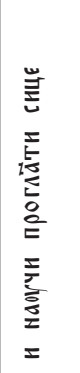 & 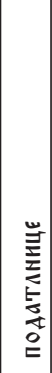 & 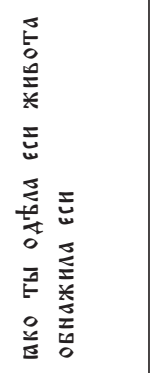 & 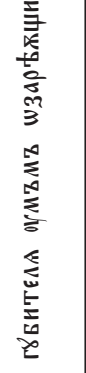 & 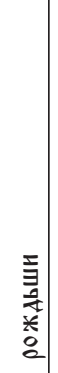 & 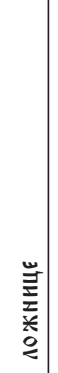 & 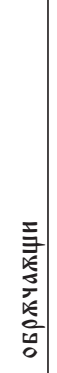 & 焉 & 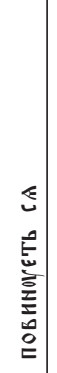 & 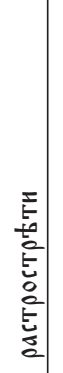 & 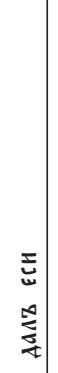 & 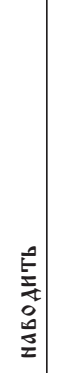 & 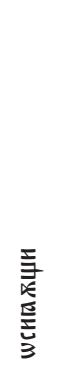 & 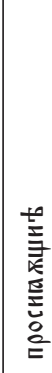 \\
\hline 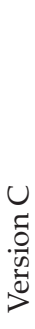 & 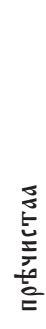 & 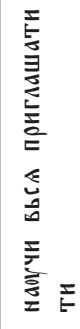 & 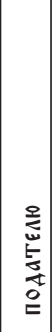 & 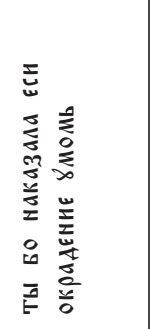 & 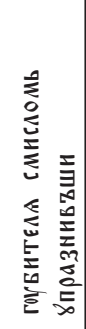 & 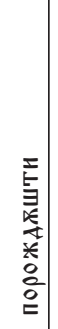 & 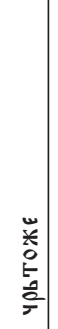 & 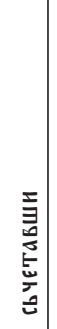 & 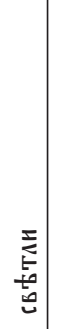 & 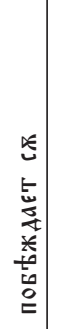 & 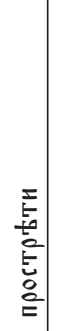 & 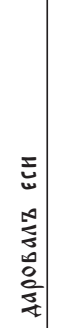 & 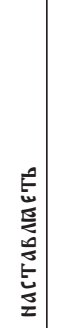 & 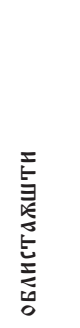 & 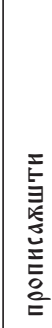 \\
\hline 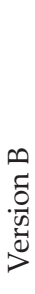 & $\begin{array}{l}\frac{5}{5} \\
\stackrel{5}{5} \\
\frac{5}{5}\end{array}$ & 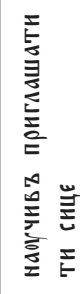 & 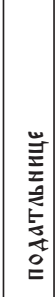 & 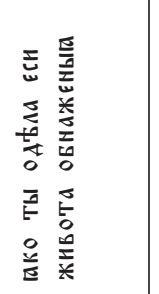 & 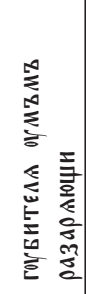 & 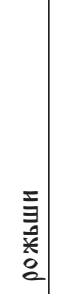 & 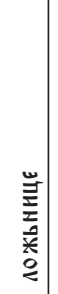 & 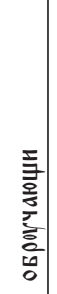 & 竭 & 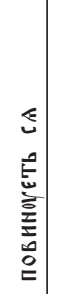 & 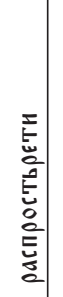 & 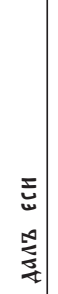 & 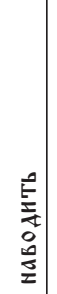 & $\begin{array}{l}\text { 言 } \\
\text { 童 } \\
\text { 。 }\end{array}$ & $\begin{array}{l}\text { 言 } \\
\text { 홀 } \\
\text { 至 } \\
\text { 을 }\end{array}$ \\
\hline 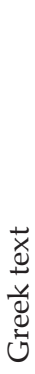 & 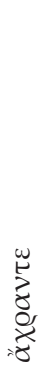 & 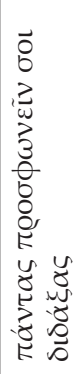 & 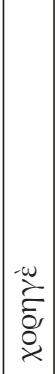 & 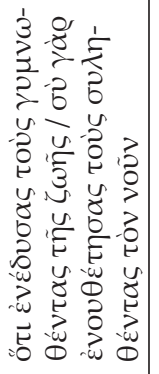 & 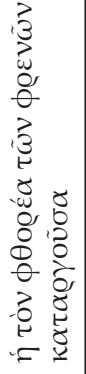 & 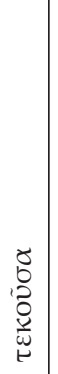 & 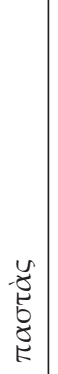 & 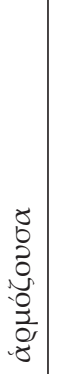 & $\frac{3}{\frac{3}{\delta}}$ & 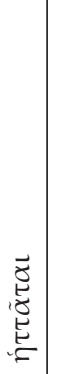 & 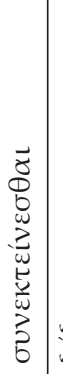 & 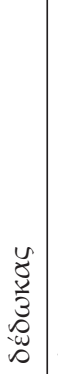 & 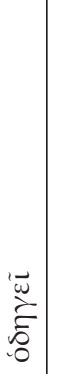 & 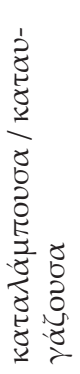 & 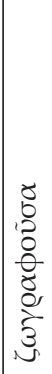 \\
\hline$\frac{0}{\ddot{0}}$ & $\stackrel{+}{\circ}$ & $\stackrel{10}{\circ}$ & $\begin{array}{l}j \\
\sigma \\
\sigma\end{array}$ & ڤ̆ & సุ' & $\stackrel{2}{\circ}$ & $\stackrel{+}{\nexists}$ & 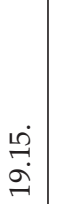 & مे & $\ddot{\sim}$ & $\dot{\sim}$ & ¿े. & $\stackrel{+}{\dot{N}}$ & $\begin{array}{l}\infty \\
\dot{\sim} \\
\dot{N}\end{array}$ & 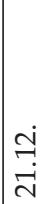 \\
\hline
\end{tabular}


Let us stress that the similarity of the East Slavonic texts of Akathistos of the version B with the text of the third part of ZMT is so striking, that any possibility of coincidence should be excluded. The differences between the texts could all be explained as the scribes' mistakes (the text of ZMT has a large number of them); no systematic text's revision definitely wasn't performed.

Thus we have found the certain parts of the version B in two South Slavonic compilations. First, the koukoulion and oikoi 1, 2 and 3 are found in the content of the compilation of manuscripts F. n. I. 68 and F. n. I. 74. Second, the large part of the text (excluding oikoi 1, 6 and 11) was used in the compilation of ZMT. The linguistic analysis of the manuscripts, containing these compilations, ${ }^{19}$ as well as the results of our investigation show that these texts were composed relatively early - surely not later than the end of the $11^{\text {th }}$ century. So we could definitely prove that though the full text of version B has never been found in the South Slavonic manuscripts it undoubtedly existed on the South Slavic territory, and from earliest times (not later than $11^{\text {th }}$ century). The last remark excludes the possibility of the later East Slavonic influence on the Southern tradition, which could have happened only later - not earlier than the end of $12^{\text {th }}$ century. Thus the presence of the version B in the South Slavic area in the $11^{\text {th }}$ century could be explained only in one way - the version B was not composed in Kiev Rus', as the certain researchers believe, but it was transported there from the South Slavic region, which was the real place of its composition.

Since almost no evidence about the literary activities in Bulgaria in the period of interest $\left(10^{\text {th }}-11^{\text {th }}\right.$ century) is left, it seems extremely difficult to determine the concrete place, time and person, who performed the new translation of Akathistos. However let us make some suppositions on the topic, which though are impossible yet to be proved, could be regarded as a possible explanation of the facts the manuscripts present us. The analysis of the manuscripts made us to believe, that the second translation of Akathistos (version B) was composed in the East Bulgarian Kingdom in the time of Tsar Peter (927-969). Let us mention that this speculation is supported by the recent publications which claim the possibility of the system-

(19) Sеe Мошин, Кирилски рукописи..., 212-213; СлавевА, Структурната еволуција..., 112-113; МоминА, Вопросы классификации..., 31. 
atic revision of all liturgical books in the time of Tsar Peter. ${ }^{20}$ According to the researchers, it was an attempt of systematic revision of all the great volume of Slavonic hymnographic material, both translated and original, from the point of view of its correspondence with the Byzantine liturgical tradition. If we assume that the version $B$ was composed in the process of this revision, than we could explain many facts we found analyzing the manuscripts. As far as the East Bulgarian Kingdom in that time was separated politically as well as culturally from the West Bulgarian, Bulgaria of Okhrid, which after the end of the East Bulgarian Kingdom represented the whole South Slavonic tradition continued to use the former version of Akathistos influenced only to the small extent by the revised one. On the other hand, the new version was borrowed and widely used by Russians, who, as it is definitely proved in the modern literature, ${ }^{21}$ took their liturgical books after their Christianization in 998 from the East Bulgarian Kingdom.

Let us sum up the main results of our investigation. As we have found out, the version of the Akathistos of the Kondakarion Typografsky, as well as of all of the East Slavonic Triodium of the $12^{\text {th }}-14^{\text {th }}$ century presents remarkable similarity with the parts of the hymn, used in the South Slavonic compilations composed not later then the $11^{\text {th }}$ century. The minimal differences had originated from the scribes' mistakes and the slight text accommodation to the East Slavonic variant of the Church Slavonic language. The texts' similarity definitely reveals, that no systematic text revision was performed over the text. Thus, it is proved, that no revision of the Akathistos was performed in the Kiev Rus' in the $11^{\text {th }}$ century (and up to the $14^{\text {th }}$ century as well), the text of the hymn the East Slavs used was composed in the South Slavic territory. We suppose that it happened in the East Bulgarian Kingdom over the time of Tsar Peter.

(20) А. А. Турилов, Б. Н. Флоря, Христианская литература у славян в середине 9 - середине 11 в. и межславянские культурные связи, in: Христианство в странах Восточной, Юго-Восточной и Центральной Европь на пороге второго тысячелетия (Москва, 2002) 415-425.

(21) В. Мошин, О периодизации русско-южнославянских иитературных связей 9-15 вв., ТОДРЛ 19 (1963) 28-106, еsp. 60-65; Г. А. ХАБУРГАЕв, Первые столетия славянской культуры: Истоки древнерусской книжности (Москва, 1994) 156-159. 


\section{SUMMARY}

The paper deals with the early stages of the history of the Old Church Slavonic translation of the Akathistos Hymn. The Greek Akathistos is stated to be translated twice into Slavonic in the $9^{\text {th }}-11^{\text {th }}$ centuries. The problems of the time and place of these translations, as well as of the relations between them are discussed. The second translation is proved to be performed in Bulgaria in the middle of the $10^{\text {th }}$ century. 